\title{
Attitudes of Young School Aged Childrens to the Teaching of Physical Education
}

\author{
Milena Mitrovic ${ }^{1}$, Katarina Dragutinovic ${ }^{1}$ \\ ${ }^{1}$ University of Montenegro, Faculty for Sport and Physical Education, Niksic, Montenegro
}

\begin{abstract}
Physical Education as an school subject has a great influence on the development of psycho-physical abilities of children. In view of this, it is important to know what the attitude of students towards the teaching of Physical Education is. The aim of our research was to determine exactly what the attitudes of the junior schoolchildrens toward the teaching of Physical Education are in the function of improving or changing the teaching process. We tried to answer the question using anonymous standardized questionnaires adapted to this research. The research involved 327 students of the 4th and 5th grade primary schools from Podgorica and Niksic. The results showed that almost all students are eager to attend classes of Physical Education, which they are very pleased to consider contributing to their health and physical development, as well as the development of friendship, strength, care, value and endurance. Most students believe that Physical Education is as important as other subjects, and that Physical Education is best performed in a schoolroom. A large number of pupils would also not change anything compared to the previous lessons. As far as favorite sports are concerned boys traditionally prefer to play football, while girls are more oriented towards volleyball, handball, rhythmic and gymnastics.
\end{abstract}

Key words: Teaching, Physical Education, Student Attitudes, Young School Age

\section{Uvod}

Fizičko vaspitanje je specifično vaspitno područje koje doprinosi razvoju čovjeka u cjelini, to nije samo podsticanje rasta i razvoja, razvijanje tjelesnih sposobnosti i unaprjeđenja zdravlja, već i znalačko korišćenje sistema fizičkih vježbi, igara i sportova, kojima se utiče na cjelokupni razvoj čovjeka (Jovanović, 1998, prema Šimleša i Potkonjak, 1989). Sličnu definiciju dali su Krulj, Kačapor i Kulić (2001), prema kojima fizičko vaspitanje predstavlja sistematski i organizovan proces sticanja motoričkih vještina, znanja i sposobnosti, jačanja zdravlja i razvoja psiho-fizičkih snaga i sposobnosti vaspitanika. Na osnovu navedenog, primjećuje se da fizičko vaspitanje predstavlja sistemski proces, koji nema uticaj samo na razvoj tjelesnih sposobnosti djeteta i čovjeka, već na njihov cjelokupni psiho-fizički razvoj (Bjelica i Petković, 2009; Bjelica i Krivokapić, 2010a, Bjelica i Krivokapić, 2019). Kao takvo, Fizičko vaspitanje doprinosi normalnom razvoju organizma, jačanju zdravlja, snaženju i čeličenju organizma, osposobljavanje za raznovrsnu pokretljivost, stvaranju higijenskih navika i obezbjeđivanju aktivnog odmora (Bakovljev, 1997). Ukoliko se uzme u obzir činjenica da savremeni način života redukuje fizičku aktivnost djece, to još više naglašava važnost Fizičkog vaspitanja kao školskog predmeta (Đorđić, 2005). Za sprovođenje kvalitetne nastave neophodni su materijalni uslovi, kao i kompetentni nastavnici, koji bi trebalo da podstiču pozitivne stavove učenika prema nastavi Fizičkog vaspitanja (N. Zrnzević i J. Zrnzević, 2015; Dragutinovic \& Mitrovic, 2019a).

Stavovi predstavljaju trajnu tendenciju da se prema nekom objektu reaguje na određeni, pozitivan ili negativan način (Rot, 1983). Oni omogućavaju sticanje fiksiranih standarda za lično prosuđivanje i shvatanje svojih postupaka. Na taj način lakše se ocjenjuju i klasifikuju objekti i situacije, što omogućava lakše i brže snalaženje i djelovanje. Kako bi nastava Fizičkog vaspitanja imala pozitivan uticaj na cjelokupni razvoj

\section{Montenegro}

Gport

\section{Correspondence:}

M.Mitrovic

University of Montenegro, Faculty for Sport and Physical Education, Narodne omladine bb, 81400, Niksic, Montenegro

E-mail: milenam1054@gmail.com 
djeteta, neophodno je da ono razvije pozitivne stavove prema njoj. Važnu ulogu u formiranju stavova djece prema Fizičkom vaspitanju imaju nastavnici, koji bi trebalo da motivišu djecu i upućuju ih na važnost fizičkog vježbanja za razvoj i zdravlje (Dragutinovic \& Mitrovic, 2019b). Pozitivne stavove je moguće formirati i kroz razne zanimljive sadržaje u procesu nastave, za šta je takođe neophodna kreativnost nastavnika. U plan nastave je neophodno uvrstiti što više takmičarskih igara, akrobatike i vježbi, različitih po svojoj strukturi, kako bi se zadovoljile dječje potrebe za kretanjem i fizičkim razvojem, ali i njegove emocionalne potrebe (Bjelica i Krivokapić, 2010b; Bjelica i Krivokapić, 2011a). Ukoliko je nastava jednolična, djeca sigurno neće steći veću naklonost prema ovom predmetu. Sa razvijanjem pozitivnih stavova neophodno je započeti što ranije, kako bi se formirala dobra osnova za dalji razvoj djeteta, kao i stekla navika bavljenja fizičkim aktivnostima i sportom.

S obzirom na važnost ovog školskog predmeta za razvoj djece, neophodno je ispitati kakve stavove djeca imaju prema nastavi Fizičkog vaspitanja, kako bi utvrdili da li ona odgovara njihovim potrebama. Stoga, osnovni cilj ovog rada je utvrditi stavove djece mlađeg školskog uzrasta prema nastavi Fizičkog vaspitanja. $\mathrm{Na}$ osnovu dobijenih rezultata, moguće je preduzeti određene mjere u pojedinim segmentima nastave, kako bi se ona poboljšala i omogućila zadovoljenje učenikovih potreba.

\section{Metod rada}

Uzorak ispitanika činilo je 327 učenika oba pola (180 dječaka i 147 djevojčica) četvrtog i petog razreda osnovnih škola "Luka Simonović" iz Nikšića i "Vuk Karadžić" iz Podgorice. Uzorak je podijeljen na četiri subuzorka, prema kriterijumima pola i uzrasta. Prvi uzorak činilo je 110 učenika četvrtog razreda, drugi subuzorak je činilo 70 učenika petog razreda, treći subzorak je činilo 74 učenica četvrtog razreda i četvrti subuzorak je činilo 73 učenice petog razreda (Tabela 1).

Tabela 1. Uzorak ispitanika

\begin{tabular}{lccc}
\hline Pol/Uzrast & IV razred & V razred & Ukupno \\
\hline Dječaci & 110 & 70 & 180 \\
Djevojčice & 74 & 73 & 147 \\
Ukupno & 184 & 143 & 327 \\
\hline
\end{tabular}

U istraživanju je korišćen anonimni standardizovani upitnik (E. Međedović, Murić i A. Međedović, 2005) koji je modifikovan i prilagođen istraživanju. Upitnik se sastojao od 10 pitanja, od kojih je devet bilo zatvorenog tipa, a jedan otvorenog tipa. Učenici su popunjavali upitnik u školi, za šta je saglasnost dao direktor škole. Popunjavanje upitnika je trajalo 15 minuta. Svi učenici su dobrovoljno popunjavali upitnike, i mogli su da odustanu u bilo kom trenutku, ali to niko nije učinio. Prikupljanje podataka je takođe sprovedeno u školi. Nakon pregleda, iz istraživanja su isključeni nepotpuno i nejasno popunjeni upitnici. Rezultati su prikazani tabebelarno (u procentima) i deskriptivno. Statistički značajne razlike u varijablama s obzirom na pol utvrđene su Pirsonovim H2 (HI kvadrat) testom na nivou značajnosti od $\mathrm{p}<0.05$.

\section{Rezultati}

U Tabeli 2 su prikazani rezultati upitnika za svako pitanje i pojedinačne odgovore kod djevojčaka četvrtog i petog razreda. Vrijednosti rezultata su prikazani brojčano i procentualno.

Tabela 2. Stavovi učenika IV i V razreda o Fizičkom vaspitanju

\begin{tabular}{|c|c|c|c|}
\hline Pitanja & Odgovori & Broj & Procenat (\%) \\
\hline \multirow[t]{2}{*}{ 1. Da li sa zadovoljstvom odlaziš na časove fizičkog vaspitanja? } & a) $\mathrm{Da}$ & 161 & 89 \\
\hline & b) $\mathrm{Ne}$ & 19 & 11 \\
\hline \multirow[t]{3}{*}{ 2. Šta najviše voliš da radiš na časovima fizičkog vaspitanja? } & a) Trčim & 16 & 9 \\
\hline & b) Igram igre & 136 & 75 \\
\hline & c) Vježbam & 28 & 16 \\
\hline \multirow[t]{3}{*}{ 3. Da li ste zadovoljni nastavom fizičkog vaspitanja u vašoj školi? } & a) Potpuno & 154 & 85 \\
\hline & b) Djelimično & 10 & 6 \\
\hline & c) Nezadovoljan & 16 & 9 \\
\hline \multirow{3}{*}{$\begin{array}{l}\text { 4. Da li vježbanje i igranje na časovima fizičkog vaspitanja pozitivno } \\
\text { utiče na zdravstveno stanje i razvitak učenika? }\end{array}$} & a) $\mathrm{Da}$ & 163 & 89 \\
\hline & b) $\mathrm{Ne}$ & 9 & 6 \\
\hline & c) Šteti zdravlju & 8 & 5 \\
\hline \multirow[t]{2}{*}{ 5. Da li bi više volio/voljela da imaš: } & $\begin{array}{l}\text { a) Lijepo i moderno } \\
\text { odijelo }\end{array}$ & 21 & 12 \\
\hline & $\begin{array}{l}\text { b) Zdravo i razvijeno } \\
\text { tijelo }\end{array}$ & 159 & 88 \\
\hline \multirow{7}{*}{$\begin{array}{l}\text { 6. Zaokruži tri sposobnosti koje se po tvom mišljenju naročito mogu } \\
\text { razviti na časovima fizičkog vaspitanja: }\end{array}$} & a) Pamćenje, & 23 & 4 \\
\hline & b) Snaga, & 95 & 18 \\
\hline & c) Drugarstvo, & 78 & 14 \\
\hline & d) Brzina, & 136 & 25 \\
\hline & e) Vrednoća, & 44 & 8 \\
\hline & f) Izdržljivost, & 156 & 29 \\
\hline & g) Muzikalnost & 8 & 2 \\
\hline
\end{tabular}


(nastavak sa prethodne strane)

\begin{tabular}{|c|c|c|c|}
\hline Pitanja & Odgovori & Broj & Procenat (\%) \\
\hline \multirow[t]{3}{*}{ 7. Šta je za učenika najbolje? } & a) Da pravilno igra & 43 & 24 \\
\hline & $\begin{array}{l}\text { b) Da rješava zadatke } \\
\text { iz matematike }\end{array}$ & 14 & 8 \\
\hline & c) I jedno i drugo & 123 & 68 \\
\hline \multirow[t]{3}{*}{ 8. Od igara koje imamo meni se posebno dopadaju: } & a) Igre u učionici & 8 & 5 \\
\hline & b) Igre u dvorištu & 29 & 16 \\
\hline & c) Igre u sali & 143 & 79 \\
\hline 9. Kada bi ste bili u prilici da nešto mijenjate u nastavi fizičkog & a) Ništa & 151 & 84 \\
\hline \multirow[t]{2}{*}{ vaspitanja, mijenjali bi ste? } & b) Uslove & 7 & 4 \\
\hline & c) Program & 22 & 12 \\
\hline
\end{tabular}

Posmatrajući Tabelu 2, uviđamo da su dječaci, prilikom odovaranja na prvo pitanje, jasno stavili do znanja da većina njih $89 \%$ voli da prisustvuje časovima Fizičkog vaspitanja, te da im ti časovi predstavljaju zadovoljstvo. Ostatak dječaka je izrazio negativan stav prema ovom predmetu (11\%).

Ono što najviše vole na časovima jesu igre, jer je njih $75 \%$ odgovorilo da su im to omiljene aktivnosti, dok su vježbanje (16\%) i trčanje (9\%) aktivnosti koje interesuju manji broj dječaka. Shodno tome, proističu rezultati sljedećeg pitanja, a koji se tiču samog procesa organizacije nastave. Dječaci su većim dijelom zadovoljni organizacijom ovih časova ( $85 \%$ ), ali postoje i oni koji su djelimično zadovoljni (6\%) i koji bi mijenjali cjelokupnu nastavu (9\%).

Koliko su djeca ovog uzrasta svjesna o važnosti ovog predmeta za zdravlje i razvoj, ukazuju odgovori koje su dječaci dali na četvrto i peto pitanje. Njih $89 \%$ je svjesno toga da nastava Fizičkog vaspitanja doprinosi zdravlju, a neki mali procenat se izjasnio da nastava ovog predmeta ne doprinosi zdravlju (6\%) ili čak da šeteti istom (5\%). Sljedeće pitanje se samo nadovezuje, i prosto daje jasniju sliku, koliko su zapravo djeca svjesna važnosti pravilnog razvoja i rasta, te je tako njih $88 \%$ odgovorilo da želi zdravo i razvijeno tijelo, dok je njih $12 \%$ stavilo zdravlje po strani.

S obrzirom na uzrast, koji je ovom prilikom obuhvaćen, možemo vidjeti da su djeca čak i u nižim razredima svjesna sposobnosti koje im razvija ova nastava. Tako su pred izdržljivosti (29\%), brzine (25\%) i snage (18\%), dječaci izdvojili i ostale sposobnosti koje su jako važne za razvoj ličnosti: drugarstvo (14\%), vrednoća (8\%), pamćenje (4\%) i muzikalnost (2\%).

Odgovorom na sedmo pitanje, dječaci su izjednačili Matematiku i Fizičko vaspitanje, te je njih $68 \%$ odgovorilo da su oba predmeta jednako važna, Fizičkom vaspitanju se priklonio ostatak $24 \%$, a samo $8 \%$ njih se opredijelilo za zadatke iz Matematike.

Većina dječaka je ocijenila fiskulturnu salu kao najpogodniji prostor za izvođenje nastave (79\%), pa čak i i igre na otvorenom (16\%), ali nikako i igre u malom i zatvorenom prostoru, učionici (5\%). Cjelokupno zadovoljstvo nastavom ovog predmeta iskazali su odgovorom na pretposlednje pitanje, gdje su odgovorili da ne bi ništa mijenjali (84\%), ali i nekoliko njih koji bi promijenili program (12\%) i uslove (4\%). Prilikom odabira sporta koji najviše vole, dječaci su u većini odgovorili da je to fudbal.

Tabela 3 prikazuje odgovore djevojčica, istog uzrasta, koje su popunjavale istu anketu i tom prilikom i one izrazile svoje stavove o nastavi Fizičkog vaspitanja i tome kako je one doživljavaju.

Tabela 3. Stavovi učenica IV i V razreda o Fizičkom vaspitanju

Pitanja
1. Da li sa zadovoljstvom odlaziš na časove fizičkog vaspitanja?

2. Šta najviše voliš da radiš na časovima fizičkog vaspitanja?

\section{Da li ste zadovoljni nastavom fizičkog vaspitanja u vašoj školi?}

4. Da li vježbanje i igranje na časovima fizičkog vaspitanja pozitivno utiče na zdravstveno stanje i razvitak učenika?

5. Da li bi više volio/voljela da imaš:

6. Zaokruži tri spsobnosti koje se po tvom mišljenju naročito mogu razviti na časovima fizičkog vaspitanja

$\begin{array}{lcc}\text { Odgovori } & \text { Broj } & \text { Procenat (\%) } \\ \text { a) Da } & 139 & 95 \\ \text { b) Ne } & 8 & 5 \\ \text { a) Trčim } & 23 & 16 \\ \text { b) Igram igre } & 93 & 63 \\ \text { c) Vježbam } & 31 & 21 \\ \text { a) Potpuno } & 134 & 91 \\ \text { b) Djelimično } & 10 & 7 \\ \text { c) Nezadovoljan } & 3 & 2 \\ \text { a) Da } & 108 & 73 \\ \text { b) Ne } & 36 & 24 \\ \text { c) Šteti zdravlju } & 3 & 3 \\ \text { a) Lijepo i moderno } & 6 & 4 \\ \text { odijelo } & & \\ \text { b) Zdravo i razvijeno } & 141 & 96 \\ \text { tijelo } & & \\ \text { a) Pamćenje, } & 26 & 6 \\ \text { b) Snaga, } & 101 & 23 \\ \text { c) Drugarstvo, } & 82 & 19 \\ \text { d) Brzina, } & 103 & 23 \\ \text { e) Vrednoća, } & 63 & 14 \\ \text { f) Izdržljivost, } & 53 & 12 \\ \text { g) Muzikalnost } & 13 & 3\end{array}$


(nastavak sa prethodne strane)

\begin{tabular}{|c|c|c|c|}
\hline Pitanja & Odgovori & Broj & Procenat (\%) \\
\hline \multirow[t]{3}{*}{ 7. Šta je za učenika najbolje? } & \multirow{3}{*}{$\begin{array}{l}\text { a) Da pravilno igra } \\
\text { b) Da rješava zadatke } \\
\text { iz matematike } \\
\text { c) I jedno i drugo }\end{array}$} & 14 & 9 \\
\hline & & 20 & 14 \\
\hline & & 113 & 77 \\
\hline \multirow[t]{3}{*}{ 8. Od igara koje imamo meni se posebno dopadaju: } & a) Igre u učionici & 9 & 6 \\
\hline & b) Igre u dvorištu & 16 & 11 \\
\hline & c) Igre u sali & 122 & 83 \\
\hline \multirow{3}{*}{$\begin{array}{l}\text { 9. Kada bi ste bili u prilici da nešto mijenjate u nastavi fizičkog } \\
\text { vaspitanja, mijenjali bi ste? }\end{array}$} & a) Ništa & 131 & 90 \\
\hline & b) Uslove & 8 & 5 \\
\hline & c) Program & 8 & 5 \\
\hline
\end{tabular}

Djevojčice su, kod prvog pitanja, jasno stavile do znanja koliko vole časove Fizičkog vaspitanja (95\%), samo njih 5\% je odgovorilo negativno. Kao i kod dječaka, najviše vole igre tokom ovih časova (63\%), dok vježbanje (21\%) i trčanje (16\%) nešto manje. Odgovorom na treće pitanje, izjasnile su se da su zadovoljne organizacijom nastave ovog predmeta, u potpunosti njih $91 \%$, dok je djelimično bilo 7\% djevojčica i samo 3\% nezadovoljnih.

Njihovi odgovori vezani za uticaj ovog predmeta na zdravlje i razvoj, dali su uvid u to koliko djevojčice zapravo znaju benefite koje on donosi sa sobom. U prilog tome govori činjenica da je na četvrtom pitanju njih $73 \%$ odgovorilo pozitivno, dok je ostatak neupućen. One su i kod petog pitanja, gdje su trebale da se odluče za zdravlje, u većini odgovorile pozitivno (96\%).

S obzirom da su dječaci većinom zaokruživale brzinu, snagu izdržljivost, kao sposobnosti koje se na ovim časovima razvijaju, djevojčice su na tom pitanju dale različite odgovore. Takođe, su ove tri sposobnosti bile u većini, ali su drugarstvo (19\%) i vrednoća (14\%), bile nešto izraženije kod njih.

Između predmeta nisu pravile razliku, te su tako kod Matematike i Fizičkog vaspitanja, odlučile se za oba predmeta (77\%), ali je $14 \%$ njih odgovorilo da su ipak važniji zadaci iz Matematike. Kao najbolji prostor za izvođenje nastave i one su odabrale fiskulturnu salu $83 \%$, zatim igre u dvorištu $11 \%$ i naposlijetku u učionici $6 \%$.

Svoje zadovoljstvo nastavom iskazale su visokim procentom (90\%), ali su podijeljena mišljenja kod mijenjanja programa 5\% i uslova $5 \%$. Kod omiljenih sportova, djevojčice su se prije odlučivale za rukomet, odbojku, ritmiku i gimnastiku.

Tabela 4. HI kvadrat test razlika stavova o Fizičkom vaspitanju između dječaka i djevojčica

\begin{tabular}{lc}
\hline \multicolumn{1}{c}{ Variables } & Sig. \\
\hline Da li sa zadovoljstvom odlaziš na časove fizičkog vaspitanja? & .017 \\
Šta najviše voliš da radiš na časovima fizičkog vaspitanja? & .062 \\
Da li ste zadovoljni nastavom fizičkog vaspitanja u vašoj školi? & .413 \\
Da li vježbanje i igranje na časovima fizičkog vaspitanja pozitivno utiče na zdravstveno stanje i razvitak učenika? & .082 \\
Da li bi više volio/voljela da imaš: & .013 \\
Zaokruži tri sposobnosti koje se po tvom mišljenju naročito mogu razviti na časovima fizičkog vaspitanja: a) snaga & 078 \\
& b) brzina \\
Šta je za učenika najbolje? & c) izdržljivost \\
Od igara koje imamo meni se posebno dopadaju: & .000 \\
Kada bi ste bili u prilici da nešto mijenjate u nastavi fizičkog vaspitanja, mijenjali bi ste? & .000 \\
\hline
\end{tabular}
Note: Sig. - statistička značajnost

Prikaz Tabele 4, nakon spreovedenog HI kvadrat testa, pokazuje gdje su postojale razlike u stavovima djevojčica i dječaka, kada je u pitanju Fizičko vaspitanje. Satistički značajne razlike su se javile kod prvog, petog, šestog i sedmog pitanja. Ono što je značajno, jeste da su kod oba pola preovladavali pozitivni stavovi.

\section{Diskusija}

Sam proces organizacije nastave Fizičkog vaspitanja iziskuje mnogo truda i kreativnosti, a pored toga i prilagođavanje nastave djeci različitog pola. Nekada su dječaci pokazivali veću sklonost ka Fizičkom vaspitanju i aktivnostima, što se može objasniti time da dječaci po uzoru na očeve većinom su uključeni u sportske aktivnosti, a djevojčice manje (Džibrić, Bašinac, Biberović i Tuzović, 2014). Međutim, to sada i nije slučaj, što se jasno može vidjeti kroz rezultate ovog istraživanja.

Kada je u pitanju zainteresovanost i zadovoljstvo prilikom nastave Fizičkog vaspitanja, veći procenat je pripao ženskom polu, odnosno djevojčicama. Baš na tom pitanju se i javila statistički značajna razlika između dječaka i djevojčica, koje su odgovorima potvrdile da zaista uživaju u fizičkim aktivnostima. S tim što tokom nastave, oba pola, radije učestvuju u igrama, nego što vježbaju ili trče. Tu su poprilično ujednačeni u svojim stavovima i nemamo statisički značajnih razlika. Oba pola, su takođe izrazila svoje zadovoljstvo procesom organizacije nastave u njihovim školama. Većina je izrazila pozitivan stav, što znači da je ovaj predmet konačno na pravom putu, gdje će se shvatiti važnost i uvažavati isti kao i svi ostali.

Učenici mlađeg školskog uzrasta su pokazali svjesnost i informisanost o važnosti Fizičkog vaspitanja za integralni razvoj ličnosti, baš kao i u prethodno sprovedenim istraživanjima (Radovanović, Madić i Nikolić, 2003; Radisavljević i Višnjić, 2004; D. Lazarević, Orlić, B. Lazarević i Radisavljević, Jelić, 2015). Zdravlje, kao veoma važan faktor za uspješan i dobar život, pospješuju 
fizičke aktivnosti (Bjelica i Krivokapić, 2011b, Bjelica i Krivokapić, 2019). Veoma je važno, još kod mlađih uzrasta da razvijemo naviku i ljubav prema njima, a sve to neće biti moguće ukoliko se djeci ne predoče sve pozitivne strane. Djeca ovog uzrasta su pokazala da znaju koliko aktivnosti doprinose njihovom zdravlju i kod oba pola, u većini, imamo pozitivne stavove. Ono što je drugačije, jeste činjenica, da su se kod djevojčica, prilikom davanja odgovora na peto pitanje, javile statistički značajne razlike u njihovu korist u odnosu na dječake. Tu je veći procenat djevojčica odlučio u korist zdravog i razvijenog tijela.

Šesto pitanje, kod kojeg je bilo dato da djeca zaokruže tri odgovora za koje smatraju da su tačni, dalo je statstički značajne razlike između dječaka i djevojčica. Ono što je za pohvalu, jeste da pored sposobnosti koje su karakteristične za ovaj predmet, djeca prepoznaju i druge koje se razvijaju tokom procesa ove nastave. Kako fizičko vaspitanje i sama fizička aktivnost van škole podsticajno djeluju na djecu, njihovu popularnost u društvu i način za druženje, sve to kod djece stvara pozitivne stavove o nastavi Fizičkog vaspitanja (Švraka, 2012). Djeca koja se bave sportom uvijek su prihvaćena u društvu i imaju osjećaj za timski rad, što dovodi do jednog skladnog života i razvoja socijlne ličnosti (Švraka, 2012). Razlika se javila, zato što su djevojčice istakle da se drugarstvo $i$ vrednoća razvijaju kroz ovaj predmet, što je kod dječaka bilo u manjem procentu.

Ono što se često pominje u školama, a veoma je važno, pogotovo u mlađem školskom uzrastu, jeste odnos prema Fizičkom vaspitanju kao predmetu. Često se smatralo da je to predmet koji je manje bitan i gdje svako može da ima visoku ocjenu, što je dovelo do nezainteresovanosti tokom nastave. Upravo zbog toga se u ovom pitanju upoređivala Matematika i Fizičko vasitanje, da bi od djece saznali šta zapravo oni misle. Većina je rekla da su oba predmeta bitna, ali onaj procenat koji se odlučio za jedan ili drugi predmet je doveo da statistički značajnih razlika kod ovog pitanja. Dječaci su u većini odlučili da je bitnije pravilno igranje, od pravilnog rješavanja zdataka, što je kod djevojčica bio obrnut slučaj.

Oba pola su bila složna kod odabira prostora za izvođenje nastave Fizičkog vaspitanja, a to je fiskulturna sala, koja se zbog prostora i opremljenosti rekvizitima čini interesantnija i primamljivija za učenje. Takođe, dvorište je pogodno za realizovanje aktivnosti, dok učionica, zbog samih uslova i deficit slobodnog prostora u oba slučaja je imala najmanji procenat. Zadovoljstvo nastavom, koje su negdje kroz prva pitanja iskazali, potvrdili su i u pretposlednjem, gdje je većina dječaka i djevojčica odgovorila da ne bi ništa mijenjali.

Deseto pitanje, koje nije prikazano u tabeli, bilo je otvorenog tipa, a djevojčice i dječaci su birali omiljeni sport. Kako je kod nas, pa tako i u svijetu najpopularniji fudbal, tako su se dječaci opredijelili za njega, dok su djevojčice imale različite odgovore gdje su za svoje omiljenje sportove istakle: odbojku, rukomet, gimnastiku i ritmiku. Moglo bi se reći da je to negdje i očekivano zbog genetskih predispozija, ali i kako je već navedeno, onoga što se plasira u njihovoj okolini.

Mjere za poboljšanje istraženog i predstavljenog stanja u pitanju stavova i poznavanja problematike fizičkog vaspitanja od strane učenika mogu se sagledati u više pravaca. Ono što treba promijeniti, da se trenutno stanje popravi, nije tako lako predložiti i prihvatiti. Međutim, moramo shvatiti da i tu postoji redoslijed važnijih i manje važnih zadataka. Treba najprije poći od našeg shvatanja da je najvažnije u radu zdravlje i vaspitanje, a poslije ovoga su operativni programski zadaci. U iznijetom izlaganju dotakli smo se samo dijela problematike vezane za sprovođenje nastave fizičkog vaspitanja. Jedan od značajnih pravaca daljeg razvoja i preobražaja ove aktivnosti je doslednije angažovanje svih onih koji vode brigu o vaspitanju i obrazovanju učenika, da preuzmu odredjene obaveze, odgovornost za stalnu brigu o nastavi fizičkog vaspitanja. Da nastoje poboljšati materijalne uslove kao i da organizuju sportske aktivnosti na način koji obezbeđuje neposrednije angažovanje učenika.

Programi fizičkog vaspitanja u školi, u budućnosti, sve više trebaju se zasnivati na stvarnim potrebama učenika, njegovih osobina, sposobnostima i interesima (Bjelica i Krivokapić, 2011a). Jedno od osnovnih pitanja u nastavi fizičkog vaspitanja, jeste pitanje cilja i zadataka. U tom pogledu fizičko vaspitanje mora se bazirati na sve izrađenijim potrebama i interesima učenika za obogaćivanjem i osmišljavanjem programa.

\section{Acknowledgements}

There are no acknowledgements.

\section{Conflict of Interest}

The authors declare that there are no conflicts of interest.

Received: 12 May 2019 | Accepted: 29 July 2019 | Published: 11 October 2019

\section{References}

Bakovljev, M. (1997). Osnovi metodologije pedagoških istraživanja. Beograd: Naučna knjiga.

Bjelica, D. i Krivokapić, D. (2010a). Teorijske osnove fizičke kulture. Podgorica: Crnogorska sportska akademija.

Bjelica, D. i Krivokapić, D. (2010b). Učenje kroz igru. In Book of abstract 2nd International Scientific Conference "Antropological aspects of sports, physical education and recreation" (25). Banja Luka: Faculty of Physical Education and Sports.

Bjelica, D i Krivokapić, D. (2019). Teorija sporta i tjelesnog vježbanja. Nikšić: Fakultet za sport i fizičko vaspitanje, Podgorica: Crnogorska sportska akademija.

Bjelica, D. i Krivokapić, D. (2011a). Teorija igre. Nikšić: Fakultet za sport i fizičko vaspitanje, Podgorica: Crnogorska sportska akademija.

Bjelica, D. i Krivokapić, D. (2011b). Zdravstveno-preventivna uloga tjelesne aktivnosti omladine. U Zborniku radova VI Međunarodne konferencije "Menadžment u sportu (144-149). Beograd: Alfa univerzitet, Fakultet za menadžment u sportu, Olimpijski komitet Srbije.

Bjelica, D. i Petković, J. (2009). Teorija fizičkog vaspitanja i osnove školskog sporta. Podgorica: Crnogorska sportska akademija, Nikšić: Fakultet za sport i fizičko vaspitanje.

Đorđić, V. (2005). Školsko fizičko vaspitanje. Novi Sad: Fakultet sporta i fizičkog vaspitanja.

Dragutinovic, K., \& Mitrovic, M. (2019a). Differences in the Attitudes of Fourth Grade Pupils of the Elementary School According to the Teaching of Physical Education in Terms of Gender. Journal of Anthropology of Sport and Physical Education, 3(1), 29-34

Dragutinovic, K., \& Mitrovic, M. (2019b). Teachers attitudes of the teaching of Physical Education. In Book of Abstract XVI Annual Scientific Conference "Sport, Physical Activity and Healt: Contemporary Perspectives" (100-101). Podgorica: Crnogorska sportska akademija, Nikšić: Fakultet za sport i fizičko vaspitanje.

Džibrić, Dž., Bašinac, I., Biberović, A. i Tuzović, A. (2014). Razlike u stavovima srednjoškolaca prema fizičkom vaspitanju. U Zborniku radova $X$ međunarodne konferencije "Izazovi savremenog menađmenta u sportu" (95-100). Beograd: Alfa univerzitet-Fakultet za menadžment u sportu, Sarajevo: Fakultet sporta i tjelesnog odgoja.

Krulj, Kačapor, Kulić (2001): Pedagogija. Beograd: Svet knjige.

Lazarević, D., Orlić, A., Lazarević, B. i Radisavljević-Jelić, S. (2015). Stavovi učenika ranog adolescentnog uzrasta prema fizičkom vaspitanju. Fizička kultura, 69(2), 88-98.

Međedović, E., Murić, B. i Međedović, A. (2005). Stavovi učenika četvrtih razreda osnovnih škola prema nastavi fizičkog vaspitanja. U Zbornik radova XI Nacionalnog naučnog skupa sa međunarodnim učešćem "Fis komunikacije 2005" (92-99). Niš: Fakultet fizičke kulture.

Radisavljević, S. i Višnjić, D. (2004). Stavovi učenika prema fizičkom vaspitanju. Godišnjak, 12, 141-153.

Radovanović, Đ., Madić, D. i Nikolić, M. (2003). Mišljenje učenika petog razreda o nastavi fizičkog vaspitanja u mlađim razredima osnovne škole. U Zbornik radova X Nacionalnog naučnog skupa sa međunarodnim učešćem "Fis komunikacije 2003" (90-93). Niš: Fakultet fizičke kulture.

Rot, N. (1983). Osnove socijalne psihologije. Beograd: Zavod za udžbenike i nastavna sredstva 
Šimleša, P. i Potkonjak, N. (1989). Pedagoška enciklopedija. Beograd: ZZUINS. Švraka, N. (2012). Stavovi mlađeg školskog uzrasta o pripadnosti grupi u nastavi fizičkog vaspitanja. SVAROG, 4, 294 - 302.
Zrnzević, N. i Zrnzević, J. (2015). Efekti nastave fizičkog vaspitanja na funkcionaIne sposobnosti učenica mlađeg školskog uzrasta. Glasnik Antropološkog društva Srbije, 50, 1-9. 